DOI: https://doi.org/10.36477/tourismhospcee-2-5

УДК 640.41(477)

П'ятницька Г. Т.

доктор економічних наук, професор, професор кафедри менеджменту Київського національного торговельно-економічного університету ORCID: https://orcid.org/0000-0003-3463-133X

Piatnytska Galyna

Kyiv National University of Trade and Economics

\title{
СТРАТЕГІЇ РОЗВИТКУ РЕСТОРАННОГО БІЗНЕСУ В УМОВАХ КРИЗИ
}

\section{RESTAURANT BUSINESS DEVELOPMENT STRATEGIES IN A CRISIS}

Проведено аналіз основних показників розвитку ресторанного бізнесу в період COVID-кризи як в Україні, так і на глобальному ринку послуг ресторанного господарства. Виділено основні характеристики COVIDкризи з урахуванням різних ознак класифікаиії криз. Визначено прийнятні для підприємств ресторанного господарства стратегії розвитку в умовах нових ринкових викликів. Ідентифіковано інноваиії у розвитку підприємств ресторанного господарства під час пандемії, ефективність та результативність впровадження яких свідчить про дочільність їх урахування у стратегіях розвитку ресторанного господарства в умовах кризи. Обтрунтовано висновок про перспективність застосування абсолютно різних стратегічних альтернатив розвитку навіть в кризових умовах ведення ресторанного бізнесу. Встановлено, щзо проактивна поведінка підприємців ресторанного бізнесу щее на початку кризи принесла кращзі результати для розвитку.

Ключові слова: ресторанний бізнес, стратегї розвитку, криза, виручка від реалізачї, управлінські рішення, ризики, ринкові виклики, інновації, підприємства ресторанного господарства.

Проведен анализ основных показателей развития ресторанного бизнеса в период COVID-кризиса как в Украине, так и на глобальном рынке услуг общественного питания. Выделены основные характеристики COVID-кризиса с учетом различных признаков классификации кризисов. Определены приемлемые для предприятий ресторанного хозяйства стратегии развития в условиях новых рыночных вызовов. Идентифициировано инновации в развитии предприятий ресторанного хозяйства при пандемии, эффективность и результативность внедрения которых свидетельствует о изелесообразности их учета в стратегиях развития ресторанного хозяйства в условиях кризиса. Обоснован вывод о перспективности применения совершенно разных стратегических альтернатив развития даже в кризисных условиях ведения ресторанного бизнеса. Установлено, что проактивная поведение предпринимателей ресторанного бизнеса еще в начале кризиса принесла лучшие результаты для развития.

Ключевые слова: ресторанный бизнес, стратегии развития, кризис, выручка от реализации, управленческие решения, риски, рыночные вызовы, инновации, предприятия ресторанного хозяйства.

A development strategies in crisis should include the implementation of a set of management measures aimed at minimizing losses from crisis phenomena, finding ways to survive and even strengthening the competitive position of the catering enterprise. Despite the analysis of recent scientific publications, the aspects of the strategic development of the restaurant business under the context of the COVID crisis are still little studied. The purpose of this study is to highlight the main characteristics of the COVID crisis with taking into account the various features of the crises 'classification, and to identify acceptable strategies for the development of catering enterprises in the face of new market challenges. To achieve this goal, general scientific and special research methods were used. It is determined that, depending on the scale of the COVID crisis, it should be attributed to global crises; by cause - to biological; and depending on the number of types of crisis phenomena generated by it and the provoked manifestation of types of risks (financial, technical, informational, collective, etc.) - to multi-risk crises. The global and multi-risk nature of the COVID crisis had a very negative impact on the development of the restaurant business both in Ukraine and in other countries. It is established that even in times of crisis there is no single development strategy for absolutely all catering companies. Its final choice depends on the strategic potential of the catering company and the opportunities to increase it in conditions of high risk and unpredictable market challenges. At the same time, the strategic choice depends on the strategic thinking of enterprise managers and their ability to make and implement effective management decisions in a crisis, to minimize losses from highly probable risk. Innovations in the development of the catering enterprises during the pandemic have been identified. The efficiency and effectiveness of the implementation of these innovations indicates the feasibility of their consideration in the strategies of restaurant development in a crisis. The COVID crisis has led to long-term negative consequences in the development of the restaurant business not only in Ukraine, but also in the global market of restaurant services. Managers of some catering companies in different parts of the world have even been forced to implement a liquidation strategy. However, there were many who chose to implement strategies of retention or even growth. In each 
case, this required the adoption and effective implementation of the managerial decisions related to either reducing costs and preventing losses due to various risks, or related to innovations aimed at confronting or even increasing the strength of the catering enterprise' competitive position in a global, multi-risk crisis. It is established that the proactive behavior of restaurant business entrepreneurs at the beginning of the crisis brought better results for the development of catering enterprises. The results of this study can be further used by both scientists and practitioners who seek to improve the strategic management of catering enterprises of various types and classes by developing new and / or implementing existing (described in the article) innovations with taking into account the possible consequences of the crisis.

Keywords: restaurant business, development strategies, crisis, sales revenue, managerial decisions, risks, market challenges, innovations, catering enterprises.

Постановка проблеми. Розвиток ресторанного бізнесу і діяльність підприємств ресторанного господарства завжди відбувається в умовах певних ринкових можливостей та загроз. При цьому деякі ринкові виклики (наприклад, такі, що були спричинені пандемією) можуть призвести до такого роду екстернальних змін, що реакція на них вимагає від менеджерів внесення кардинальних коректив до стратегій розвитку підприємств ресторанного господарства. Стратегії розвитку в умовах кризи мають передбачувати реалізацію цілого комплексу управлінських заходів, спрямованих на мінімізацію втрат від кризових явищ, пошуку шляхів для виживання та навіть зміцнення конкурентних позицій підприємства / закладу ресторанного господарства (РГ) на ринку.

Bce вищезазначене актуалізує проблематику встановлення того, які саме стратегії розвитку підприємствам / закладам РГ в умовах кризи доцільно та можна реалізувати, виходячи 3 наявного досвіту їх діяльності в період пандемії, що спричинила цілу низку негативних явищ та збільшила кількість загроз на ринку ресторанних послуг. Крім того, з точки зору практики розвитку ресторанного бізнесу $є$ необхідність у чіткому визначенні таких управлінських рішень, які виявилися дієвими в умовах COVID-кризи та позитивно впливатимуть на прогресивний розвиток підприємств РГ і у стратегічній перспективі.

Аналіз останніх досліджень і публікацій. Варто наголосити, що проблематика стратегічного управління розвитком підприємств $\epsilon$ не новою i була предметом досліджень таких іноземних та українських науковців, як: I. Ансофф, М. Портер, Г. Мінцберг, П. Друкер, А. Мазаракі, А. Наливайко, 3. Шершньова та ін. Останнім часом науковці зосереджували особливу увагу на вивченні таких аспектів, як: розвиток методів стратегічного управління Web проектами (С. Федушко та ін. [1]); визначення сутності та класифікація стратегій розвитку (С. Василига [2]); стратегії та потенціал соцільного розвитку організацій (В. Жуковська [3]); стратегічне управління розвитком персоналу підприємств (В. Малтиз, А. Батраченко [4]) та стратегічне управління розвитком трудового потенціалу у агробізнесі (I. Пішенін [5]) тощо. Окремі дослідження були присвячені розвитку підприємств ресторанного господарства в період пандемії. Так, Дж. Кім та деякі інші науковці [6] дослідили питання фінансових результатів діяльності ресторанів внаслідок прояву негативних ефектів від пандемії. Окремі дослідження стосувалися і проблематики проактивних і реактивних стратегій розвитку ресторанів в кризових умовах, що передували пандемії (М. Алонсо-Алмейда та ін. [7]) та ідентифікації тенденцій розвитку підприємств ресторанного господарства, що позитивно позначаються на реалізації їх лідерського потенціалу, та макроекономічних факторів, які перешкоджають реалізації лідерства (М. Барна та ін. [8]). У деяких наших попередніх дослідженнях [9-11 та ін.] також піднімалися проблемні питання щодо стратегій розвитку підприємств / закладів РГ та впровадження різних інновацій для прийняття та реалізації таких управлінських рішень, які будуть сприяти їх розвитку навіть в умовах домінування ринкових загроз.

Виділення невирішених раніше частин загальної проблеми. Незважаючи на вищенаведені наукові публікації, аспекти стратегічного розвитку ресторанного бізнесу в умовах COVIDкризи залишаються все ще мало вивченими. Підприємці у сфері ресторанного бізнесу стикнулися 3 абсолютно новим видом ринкових викликів для розвитку підприємств РГ, оскільки наслідки COVID-кризи лише частково можна порівняти 3 наслідками інших типів криз.

Метою цього дослідження є: виділення основних характеристик COVID-кризи, зважаючи на різні ознаки класифікації криз, та визначення прийнятних для підприємств / закладів РГ стратегій розвитку в умовах нових ринкових викликів. Для досягнення мети поставлені та виконані такі завдання: 1) провести аналіз показників розвитку ресторанного бізнесу в Україні та на глобальному ринку (у інших країнах світу) в період COVIDкризи; 2) ідентифікувати інновації у розвитку підприємств / закладів РГ в період пандемії.

У ході дослідження були використані загальнонаукові та спеціальні методи дослідження, а саме: індукції та дедукції, аналізу та синтезу, порівнянь та класифікації, статистичної обробки даних, графічний та інші.

Інформаційною базою слугували власні дослідження автора, дані Державної служби статистики України, Аналітичного центру «Ресторани Укра- 
їни», OpenTable, результати досліджень компаній «Делойт», Square та Wakefield Research тощо.

Виклад основного матеріалу дослідження. Мережа ресторанного господарства у будьякій країні світу, як правило, поділяється на дві частини: 1) загальнодоступну, підприємства (заклади) РГ якої фактично займаються ресторанним бізнесом, намагаючись максимізувати свою ринкову вартість та прибутки; 2) умовно закритого типу, що надає послуги з організації харчування за місцем навчання та / або роботи і т.П., де послуги підприємств (закладів) РГ є супутніми та часто більшою мірою орієнтовані на задоволення потреби у забезпеченні якості життєдіяльності їх споживачів, відновлення їх енерговитрат та задоволення фізіологічних потреб протягом доби (звичайно бажано 3 хоч мінімальною прибутковістю). У зв'язку з цим вибір / формування стратегій розвитку підприємств (закладів) РГ двох дещо різних за цільовими установками мереж ресторанного господарства не може бути абсолютно однаковим навіть в умовах кризи. Останнє, зокрема, підтвердили й відмінності в управлінських рішеннях та інноваціях, що запроваджували та продовжують реалізувати діючі підприємства (заклади) РГ в період COVID-кризи.

Залежно від масштабу прояву COVID-кризу варто віднести до глобальних криз; за причиною виникнення - до біологічних; а залежно від кількості генерованих нею різновидів кризових явищ (соціально-демографічного, фінансово-економічного, логістично-комунікаційного і т.п. характеру) та спровокованого прояву різновидів ризиків (фінансових, технічних, інформаційних, колективних та ін.) - до мультиризикових криз. Глобальність та мультиризиковість COVID-кризи, на жаль, в цілому дуже негативно вплинула на розвиток ресторанного бізнесу як в Україні (рис. 1), так і в інших країнах світу (рис. 2).

Глобальний ринок послуг ресторанного господарства навіть за станом на кінець травня 2021 р. у цілому ще перебуває у стадії поступового відновлення звичайного режиму роботи закладів РГ після рецесії. У деяких країнах за показниками зайнятості місць у закладах РГ (зокрема, США, Німеччині та ін.) зайнятість і, як наслідок, оборот-

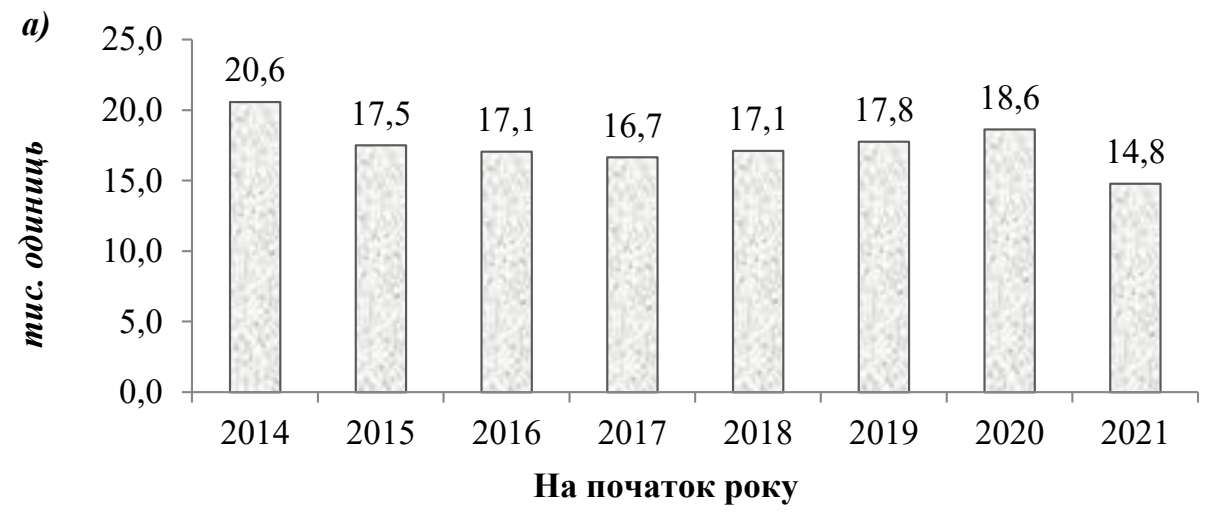

б) Відсотки зменшення виручки

Відсотки збільшення виручки

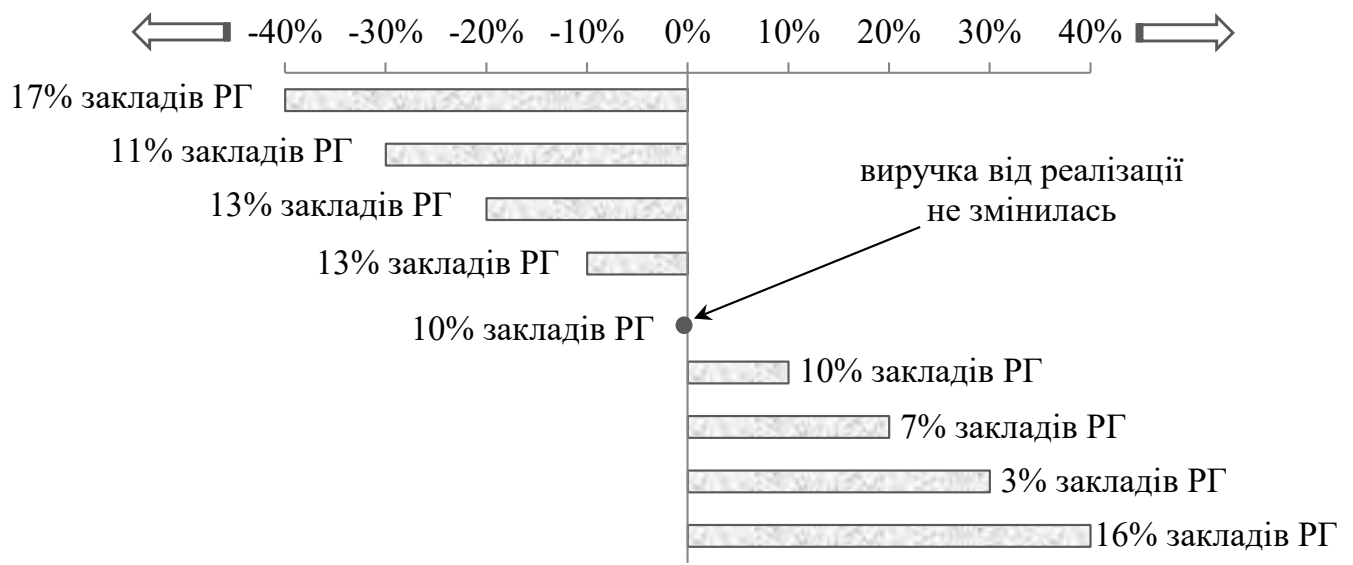

Рис. 1. Розвиток ресторанного господарства в Україні:

а) динаміка кількості закладів РГ протягом 2014-2021 рр.*;

б) зміна виручки від реалізації у закладах РГ липень 2020 р. до липня 2019 р.**

Примітки: * За даними Аналітичного центру «Ресторани України» та Державної служби статистики України [12; 13, с. 114]. ** Побудовано автором за даними компанії з автоматизації кафе, ресторанів і магазинів Роster на основі інформації про продажі 550 закладів РГ України, з регіонів де у липні 2020 р. була дозволена їх робота у повноцінному форматі [14]. 


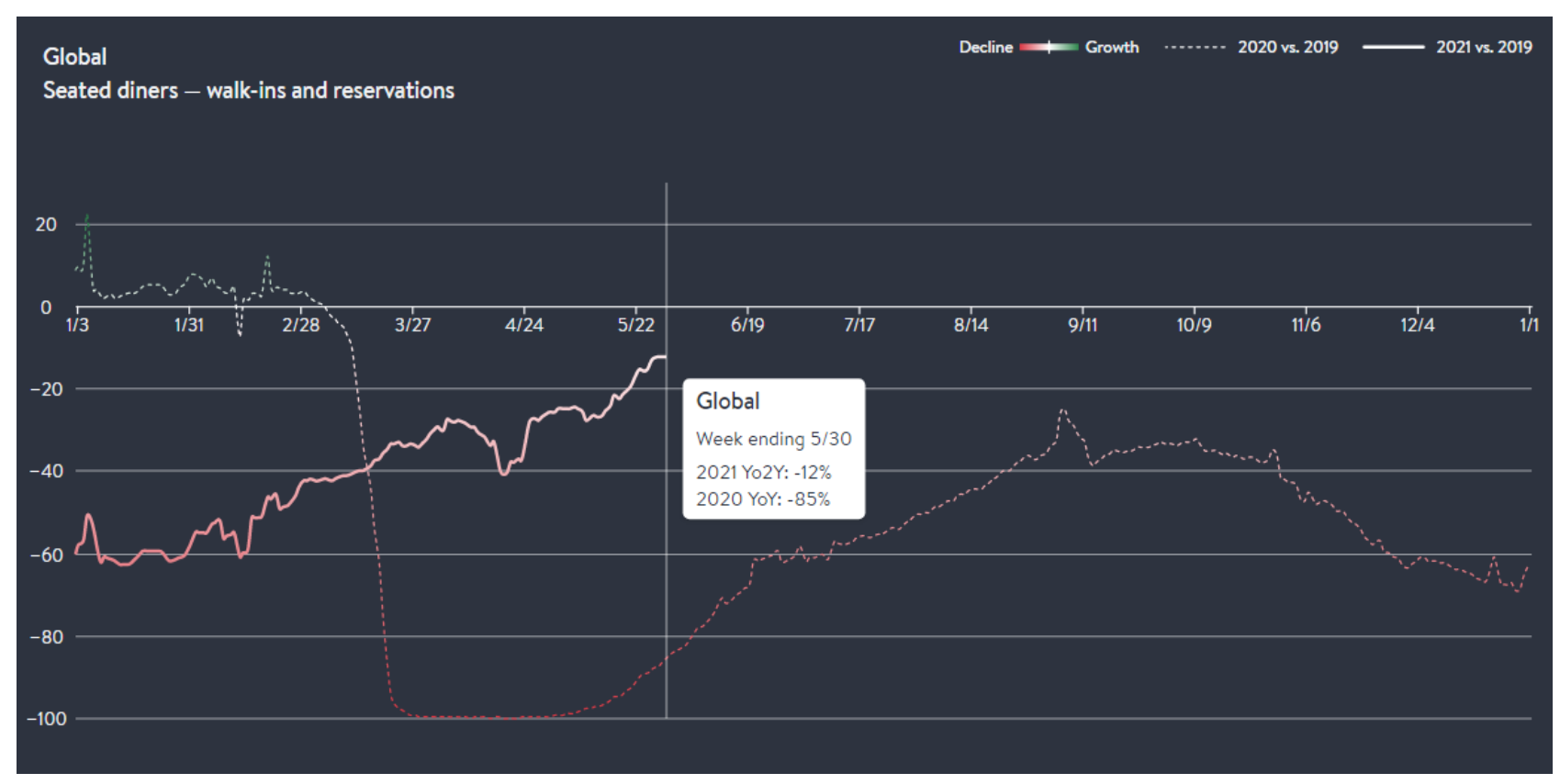

Рис. 2. Динаміка зайнятості місць у закладах РГ на глобальному ринку послуг ресторанного господарства* протягом 1.01.2020-30.05.2021

у порівнянні з динамікою відповідного показника у 2019 році**

Примітки: * За даними найкращих закладі РГ, що представлені в OpenTable та відкрилися і почали знову обслуговувати споживачів на місцях та приймають замовлення по всьому світу. Глобальний ринок послуг РГ в ОpenTable представлений закладами РГ 3 таких країн, як: США, Німеччина, Австралія, Мексика, Великобританія, Канада, Ірландія.

** Скріншот з сайту компанії OpenTable [15] в режимі реального часу за станом на 30.05.2021. Графіки відображають зміну зайнятості місць, що були зарезервовані он-лайн, за мобільним додатком або на місці на конкретну дату у 2020-2021 рр. по всім вище охарактеризованим закладам РГ у порівнянні з відповідним показником у 2019 р.

ність місць у закладах РГ ще далека від відповідних показників 2019 року до початку розгортання COVID-кризи (див. рис. 2).

Негативні наслідки COVID-кризи проявилися i у зменшенні кількості закладів РГ та падінні обсягів виручки від реалізації у більш, ніж половини 3 тих 3 них, що не пішли 3 ринку ресторанних послуг й України (див. рис. 1). Ці тенденції, передусім, були пов'язані 3 обмеженнями в режимі роботи підприємств (закладів) РГ, необхідністю створення належних умов для дотримання соціальної дистанції та інших санітарно-епідеміологічних правил у зв'язку з безпрецедентними швидкістю поширення та наслідками для здоров'я людей вірусу, до чого виявилися готові далеко не всі ресторатори. Зазначене спричинило зростання втрат, оскільки надання послуг більшістю типів підприємств / закладів РГ передбачає прямий або достатньо тісний опосередкований контакт як між споживачами ресторанних послуг і обслуговуючим персоналом цих підприємств / закладів, так і між різними групами самих споживачів (особливо якщо крім організації харчування на підприємстві РГ надаються послуги з організації розваг).

Як свідчать дані рис. 1а в Україні внаслідок COVID-кризи кількість закладів РГ протягом останнього року зменшилась на понад $20 \%$ і за станом на початок 2021 р. налічувала 14786 закладів РГ. Водночас навіть у регіонах, де у певні часові періоди 2020 р. була дозволена повноцінна робота підприємств / закладів РГ, роздрібний товарооборот РГ суттєво зменшився, про що, зокрема, свідчить зменшення у липні 2020 р. порівняно 3 аналогічним періодом 2019 р. виручки від реалізації у 54 \% закладів РГ. При цьому у 28 \% закладів РГ це зменшення становило $30 \%$ і більше (рис. 1б). Однак, згідно з рис. 1б, в Україні були підприємства / заклади РГ, що змогли визначити правильні стратегічні орієнтири для свого розвитку у період COVID-кризи та навіть збільшили свою виручку від реалізації. Звичайно у кожному конкретному випадку могли бути різні причини подібного зростання. Варто наголосити, що далеко не всі 3 них були пов'язані виключно 3 реалізацією стратегії, орієнтованої на підвищення цін та скорочення персоналу i, як наслідок, зменшення обсягів витрат на заробітну плату. Проте, наприклад, заклади холдингу «!Fest» за підсумками першого року карантину не змогли повернути на роботу близько 20 \% працівників [16].

Непоодинокими були випадки, коли заклади РГ почали впроваджувати різного роду інноваціï: як такі, що реалізували і в попередні часові періоди (наприклад, продуктові інновації в меню), так і такі, що були абсолютно новими для певних закладів РГ (наприклад, організація співпраці 3 компаніями доставки їжі). За даними досліджень компанії «Делойт», яка нещодавно презентувала 
результати вивчення поведінки українських споживачів, що сформувалися під впливом COVIDкризи, та у тому числі позначились на стратегіях розвитку підприємств / закладів РГ, доставка їжі стала одним 3 ключових трендів на ринку ресторанних послуг в період жорсткого локдауну. У цілому за результатами опитування 1600 респондентів з усіх регіонів України (крім тимчасово окупованих АР Крим, м. Севастополь та території ОРДЛО) було встановлено, що нині [17, с. 19]:

- $73 \%$ українців користується сервісами доставки готової їжі та продуктів харчування;

- до топ-3 сервісів з доставки готової їжі та продуктів харчування в Україні за оцінками респондентів потрапили: Glovo (18\%); Rocket (10\%); власні служби доставки закладів РГ (12\%);

- чим більший населений пункт України, тим його жителі частіше користуються сервісами доставки готової їжі: 81 \% мешканців мегаполісів $\epsilon$ користувачами сервісів доставки готової їжі та продуктів харчування;

- $64 \%$ українців зменшили частоту відвідування ресторанів та / або барів в період пандеміі;

- 47 \% респондентів зменшили свої витрати на ресторани та / або бари в період COVID-кризи;

- 43 \% почали більше витрачати на доставку готової їжі та продуктів харчування.

Проте власники-керівники та / або менеджери далеко не всіх закладів РГ, змінюючи стратегію свого розвитку в умовах COVID-кризи, прийняли рішення про введення до своїх бізнес-моделей послуг доставки. Так, за даними опитування приблизно 2,4 тис. рестораторів, яке організувала та провела наприкінці 2020 р. 3 використанням телеграмканалу компанія «БізРейтинг» [18], було з'ясовано, що $33 \%$ вважають таке нововведення для себе неприйнятним; 21 \% наголосили, що доставка в них була і до карантину. Водночас на користь посилення значущості тренду розбудови каналів доставки та запровадження відповідних послуг у сфері РГ України свідчать такі дані опитування [18]:

- $16 \%$ респондентів-рестораторів повідомили про запуск власної доставки саме в період COVID-кризи;

- 14 \% наголосили, що карантин змусив їх розвинути послуги доставки, хоча вони були в них $і$ до цього;

- $5 \%$ запустили доставку 3 використанням стратегії аутсорсингу, тобто близько 120 рестораторів для реалізації цієї послуги вирішили залучити сторонні компанії, що спеціалізуються на сервісі доставки;

- 11 \% зауважило, що хоча поки така інновація не запроваджена, але є плани щодо обов'язкової організації та надання послуги доставки їжі у їх закладах РГ.

Іншими інноваціями, щодо яких у 2020 р. менеджери ряду підприємств / закладів РГ вже при- йняли позитивні управлінські рішення про впровадження або які заклади РГ з різних країн світу реалізуватимуть у межах стратегій свого розвитку протягом 2021 р., а також ті, на які їм варто звернути увагу зважаючи на очікування споживачів ресторанних послуг в період COVID-кризи, згідно з результатами досліджень компанії Square [19], що співпрацювала з Wakefield Research для опитування 500 рестораторів, 1000 споживачів ресторанних послуг та галузевих експертів, та нашими власними дослідженнями є наступні:

- технології автоматизації кухні: 91 \% опитаних рестораторів реалізують або планують інвестувати у названі технології;

- безконтактні варіанти замовлення та оплати за всіма каналами реалізації послуг закладами РГ: така інновація за прогнозними оцінками запланована в 3-х з чотирьох закладів РГ. Зауважимо, що $61 \% 3$ опитаних рестораторів вже використовують безконтактні платежі на місці;

- створення та/або розвиток власного вебсайту або спеціального додатку, оскільки 67 \% опитаних споживачів воліють сьогодні використовувати веб-сайт підприємства / закладу РГ або додаток для доставки їжі;

- цифрове меню: майже половина опитаних власників та менеджерів ресторанів планує i надалі розвивати цифрове меню та пропонувати до нього доступ за допомогою URL-адрес або QR-кодів і у 2021 р.;

- продуктові інновації: 92\% респондентів-рестораторів готові експериментувати зі своїм меню та надалі впроваджувати продуктові інновації;

- розвиток культу чистоти та безпеки відвідувачів та працівників підприємств / закладів РГ як різновид нових організаційних інновацій у сфері РГ в період пандемії та після подолання іiі загроз;

- використання соціальних мереж для просування продукції та послуг підприємств / закладів РГ та зміцнення їх конкурентних позицій на ринку. На користь інноваційних змін просування послуг ресторанного господарства через соціальні мережі свідчать такі факти, як [20]: у Twitter продукти харчування і напої згадують у 32\% постів; У Instagram хештег\#food є 25-м найпопулярнішим хештегом в світі - майже 400 мільйонів повідомлень на платформі помічені тегом \#food; 36 \% американських відвідувачів стежать за ресторанами в соціальних мережах, і 39 \% з них роблять це, щоб визначити, чи хочуть вони замовити їжу в закладі РГ тощо. Важливість присутності у соціальних мережах для розвитку підприємств РГ сьогодні усвідомлюють і українські підприємці, які стають активними користувачами соціальних мереж, у т.ч. 3 метою просування свого ресторанного бізнесу в прцесі його розвитку. Про це, зокрема, свідчать відповідні ініціативи підприємця Д. Борисова (сім'я ресторанів Діми Борисова) [21]. 
Безумовно можливості (передусім, фінансові та технічні) у різних підприємств РГ - неоднакові, а тому і їх організаційні здатності реалізувати інноваційну стратегію розвитку в період COVID-кризи суттєво різняться. Проте, як виявили наші дослідження, що проводились протягом березня 2020 березня 2021 р., підприємства / заклади РГ у період ринкових викликів, спричинених COVID-кризою доволі часто пов'язували свою стратегію розвитку з певного роду інноваціями (рис. 3). Хоча безумовно на глобальному ринку ресторанних послуг були й ті, які в силу низки причин реалізували різновиди стратегій скорочення, у т.ч. повної ліквідації.

Отже, згідно з результатами наших досліджень (див. рис. 3), навіть в умовах кризи немає єдиної стратегії розвитку. Ї̈̈ остаточний вибір залежить від наявного у підприємства / закладу РГ стратегічного потенціалу та можливостей його нарощення в умовах високого рівня ризиків та непередбачуваних ринкових викликів.

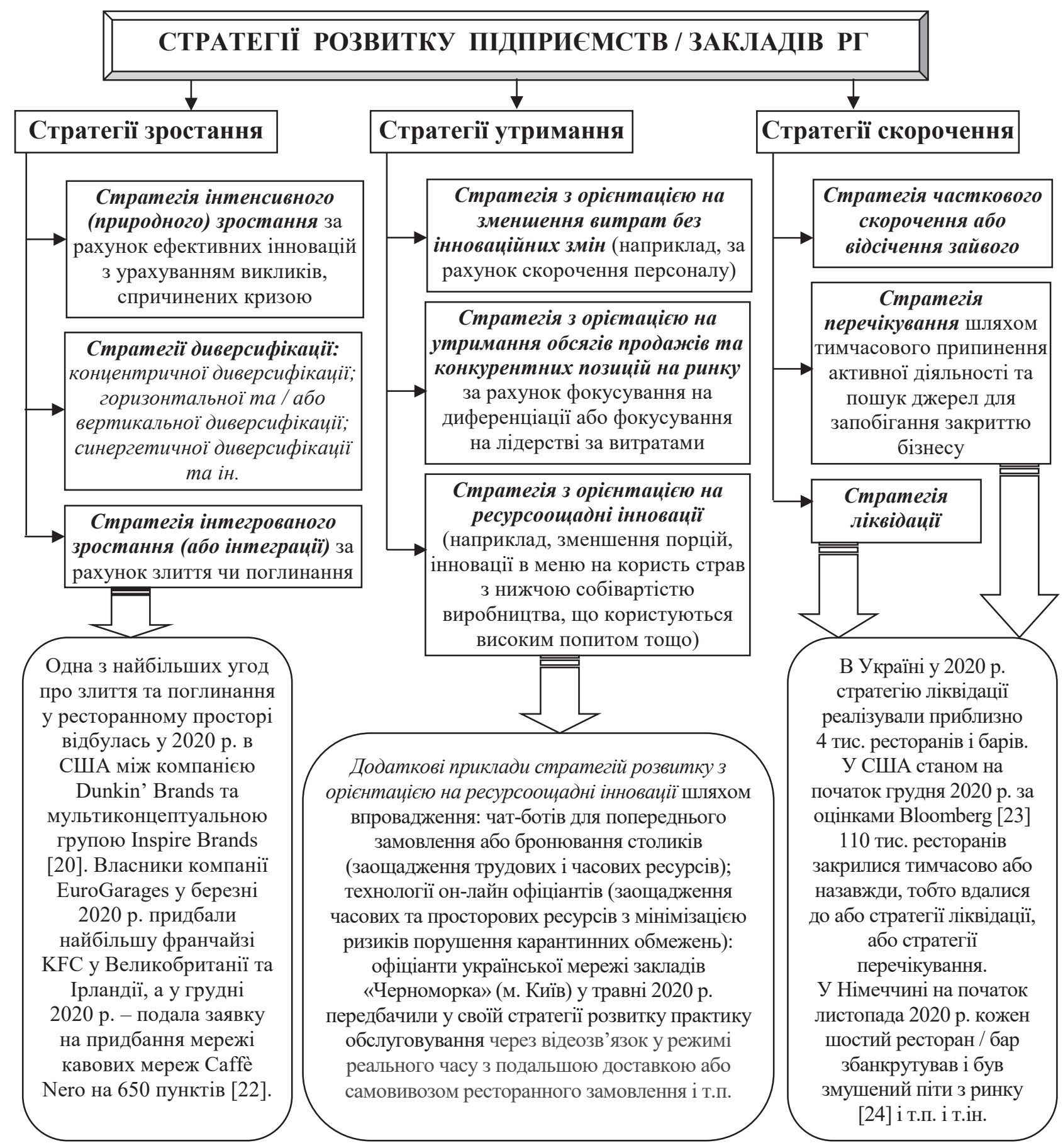

Рис. 3. Альтернативні стратегії розвитку підприсмств / закладів ресторанного господарства в умовах COVID-кризи*

Примітка. * Розроблено автором з наведенням окремих прикладів. 
Водночас стратегічний вибір залежить і від стратегічного мислення менеджерів підприємств та їх здатностей в умовах кризи приймати та реалізувати ефективні управлінські рішення, мінімізувати втрати від високо ймовірного прояву ризиків. При цьому керівникам підприємств РГ варто звертати особливу увагу як на ризики забезпечення фінансової безпеки підприємств РГ, так і країн, де відбувається розвиток ресторанного бізнесу. Іншими словами, «у кожному конкретному випадку забезпечення фінансової безпеки потребуватиме прийняття своїх унікальних рішень, зважаючи на вихідні дані щодо стану фінансової системи підприємства / країни та фактори, що впливають на їі функціонування та розвиток» [25]. Забезпечення фінансової стійкості на підприємствах РГ є однією з обов'язкових передумов для результативної реалізації їх стратегій зростання на ринку навіть в умовах прояву у зовнішньому середовищі негативних наслідків кризових явищ.

Висновки. Підводячи підсумки констатуємо, COVID-криза призвела до довгострокових негативних наслідків у розвитку ресторанного бізнесу не тільки в масштабах України, але і глобального ринку ресторанних послуг. Менеджери деяких підприємств / закладів РГ у різних куточках світу були змушені навіть вдатися до реалізації стратегії ліквідації. Проте було достатньо багато і тих, хто обрав курс на реалізацію стратегій утримання або навіть зростання. У кожному конкретному випадку це вимагало прийняття та результативної реалізації управлінських рішень, пов'язаних або зі скороченням витрат і запобіганням втрат внаслідок різного роду ризиків, або з інноваціями, спрямованими на протистояння чи навіть нарощення сили своїх конкурентних позиців в умовах глобальної, мультирозикової кризи.

Наслідки застосування варіативних підходів до коригування стратегій розвитку менеджерами підприємств / закладів РГ у період пандемії свідчить про перспективність абсолютно різних стратегічних альтернатив навіть в кризових умовах ведення ресторанного бізнесу. Проте безумовно в кращій ситуації опинилися ті підприємці ресторанного бізнесу, які, по-перше, не очікували швидкого закінчення кризи i активно та при цьому дуже зважено почали вносити зміни у стратегію розвитку своїх підприємств ще на початку поширення COVID та оголошення локдаунів. По-друге, нові зовнішні ринкові загрози не були накладені на переважно слабкі сторони у діяльності та розвитку підприємства РГ, що сформувалися протягом попередніх часових періодів.

Вважаємо, що результати цього дослідження у подальшому можуть бути використані як науковцями, так і практиками, які прагнитимуть удосконалити стратегічне управління підприємствами / закладами РГ різних типів і класів з загальнодоступної мережі РГ шляхом розробки нових та / або впровадження наявних (вище охарактеризованих) інновацій 3 урахуванням прояву варіативних наслідків імовірних криз, що впливатимуть і на діяльність, $\mathrm{i}$ на розвиток цих підприємств / закладів.

\section{Список використаних джерел:}

1.Fedushko, S., Perácek, T., Syerov, Y., Trach, O. (2021). Development of Methods for the Strategic Management of Web Projects. Sustainability. Vol. 13, 742. URL: https://www.mdpi.com/2071-1050/13/2/742 (дата звернення: 28.05.2021).

2.Жуковська В.М. (2018). Соиіальний розвиток організаџиї: потенціал, управління, інновацї:: [монографія]. Київ : Київ. нац. торг.-екон. ун-т, 360 с.

3.Василига С.М. (2020). Поняття стратегії розвитку підприємства. Економіка та держава. № 1. С. 121-125.

4.Пішенін І.К. (2018). Стратегічне управління розвитком і відтворенням трудового потенціалу у секторальних сферах економіки. Економічний аналіз: зб. наук. пращь. Тернопіль : Видавничо-поліграфічний центр Тернопільського національного економічного університету «Економічна думка». Том 28. № 1. С. 87-91.

5. Малтиз В.В., Батраченко А.О. (2020). Сучасний підхід до стратегічного управління розвитком персоналу підприємств. Молодий вчений, № 3(79). С. 233-236.

6.Kim, J., Kim, J., Lee, S.K., Tang, L. (2020). Effects of epidemic disease outbreaks on financial performance of restaurants: Event study method approach. Journal of Hospitality and Tourism Management. Vol. 43. P. 32-41.

7. Alonso-Almeida, M.d.M., Bremser, K., Llach, J. (2015). Proactive and reactive strategies deployed by restaurants in times of crisis: Effects on capabilities, organization and competitive advantage. International Journal of Contemporary Hospitality Management. Vol. 27. P. 1641-1661.

8. Барна М., Бабенко О. (2017). Соціально-економічні передумови лідерства на підприємствах ресторанного господарства. Економічний дискурс. № 4. С. 57-66.

9. П’ятницька Г.Т., Григоренко О.М., Найдюк В.С. (2017). Інновації у розвитку підприємств ресторанного господарства: міжнародні тренди та українські реалії в умовах домінування ринкових загроз. Підприємниџтво $i$ торгівля. Вип. 21. С. 119-128.

10.П'ятницька Г., Григоренко О., Долженко Т. (2021). Дихотомія інноваційних трансформацій підприємств. Зовнішня торгівля: економіка, фінанси, право. № 2. С. 30-43. Серія : Економічні науки.

11.П'ятницька Г. Найдюк В. (2018). Мультиваріативність стратегій інноваційного розвитку. Зовнішня торгівля: економіка, фінанси, право. № 1. С. 22-36. Серія : Економічні науки.

12.Аналітичний центр «Ресторани України» (2021). Розвиток ресторанного господарства України за кількістю закладів. URL: https://www.facebook.com/102348505275876/photos/a.114870357357024/114870250690368/?type=3 (дата звернення: 28.05.2021). 
13.Державна служба статистики України (2014). Мережа роздрібної торгівлі та ресторанного господарства підприємств на 1 січня 2014 року: стат. бюл. Київ, ДССУ. 125 с.

14.Poster (2020). Насколько просели по выручке заведения в Украине в июле 2020 года. URL: https://joinposter.com/ post/prosadka-piviruchke-v-ukraine (дата звернення: 28.05.2021).

15.OpenTable (2021). The restaurant industry in recovery. URL: https://www.opentable.com/state-of-industry (дата звернення: 30.05.2021).

16.Вінокуров Я. (2021). Рік - плюс, ФОП - мінус: як малий бізнес пережив перший рік карантину. Економічна правда. URL: https://www.epravda.com.ua/publications/2021/03/24/672241/ (дата звернення: 28.05.2021).

17.Deloitte (2021). Споживацькі настрої украӥнців у 2020 році. ТОВ «Делойт енд Туш ЮСК». 111 с.

18.BizRating (2020). Как работает бизнес доставки еды. URL: https://bizrating.com.ua/6/articles/1395/index.html (дата звернення: 28.05.2021).

19.Keefer, K. (2021). Restaurants are Investing and Innovating. URL: https://squareup.com/us/en/townsquare/futureof-restaurants (дата звернення: 28.05.2021).

20.Petre, H. (2020). 28 mergers and acquisitions in the restaurant industry in 2020. Nation's Restaurant News. URL: https://www.nrn.com/mergers-acquisitions/28-mergers-and-acquisitions-restaurant-industry-2020 (дата звернення: 28.05.2021).

21.Бовшовська С. (2021). Чому соцмережі для власників бізнесу та СЕО - це «маст-хев» у 2021 році? Бізнес. URL: https://www.business.ua/uk/node/11462

22. Otterburn, S. (2021). M\&A market overview - Restaurant and Bars 2021. BDO (UK). URL: https://www.bdo.co.uk/ en-gb/insights/industries/leisure-and-hospitality/restaurant-and-bars-2021-m-a-market-overview (дата звернення: 28.05.2021)

23.Gonzalez, C. (2020). Restaurant Closings Top 110,000 With Industry in 'Free Fall'. Bloomberg. URL: https://www.bloomberg.com/news/articles/2020-12-07/over-110-000-restaurants-have-closed-with-sector-in-free-fall (дата звернення: 28.05.2021).

24.Kinkartz, S. (2020). Coronavirus: Berlin's restaurants are dreading the Christmas season. $D W$. URL: https://www.dw.com/en/coronavirus-berlins-restaurants-are-dreading-the-christmas-season/a-55618730 (дата звернення: 28.05.2021).

25.П'ятницька Г.Т., Федулова І.В. (2020). Фінансова безпека країни та підприємства: визначення, взаємозв'язок i ризики забезпечення. Ефективна економіка. № 7. URL: http://www.economy.nayka.com.ua/?op=1\&z=8059 (дата звернення: 28.05.2021).

\section{References:}

1. Fedushko, S., Perácek, T., Syerov, Y., Trach, O. (2021). Development of Methods for the Strategic Management of Web Projects. Sustainability, vol. 13, 742. URL: https://www.mdpi.com/2071-1050/13/2/742 (accessed 28 May 2021).

2.Zhukovska, V.M. (2018). Sotsialnyi rozvytok orhanizatsii: potentsial, upravlinnya, innovatsii [Social development of the organization: potential, management, innovations]. Kyiv: KNUTE. (in Ukrainian)

3. Vasylyha, S. (2020). Concepts of enterprise development strategy, Ekonomika ta derzhava, vol. 1, pp. 121-125. (in Ukrainian)

4. Pishenin, K.I. (2018). Strategic management of development and reproduction of labor potential in sectoral areas of the economy, Ekonomichnyi analiz, vol. 28, issue 1, pp. 87-91. (in Ukrainian)

5. Maltyz, V.V., Batrachenko, A.O. (2020). A modern approach to strategic management of enterprise personnel development, Young scientist, vol. 3, issue 79, pp. 233-236.

6. Kim, J.. Kim, J.. Lee, S.K.. Tang, L. (2020). Effects of epidemic disease outbreaks on financial performance of restaurants: Event study method approach. Journal of Hospitality and Tourism Management, vol. 43, pp. 32-41.

7. Alonso-Almeida, M.d.M., Bremser, K., Llach, J. (2015). Proactive and reactive strategies deployed by restaurants in times of crisis: Effects on capabilities, organization and competitive advantage. International Journal of Contemporary Hospitality Management, vol. 27, pp. 1641-1661.

8. Barna, M., Babenko, O. (2017). Socio-economic prerequisites for leadership in the restaurant industry. Economichnyi Diskurs, vol. 4, pp. 57-66. (in Ukrainian)

9. Piatnytska, G.T., Hryhorenko, O.M., Naidiuk, V.S. (2017). Innovations in the development of restaurant enterprises: international trends and Ukrainian realities in the conditions of dominance of market threats. Pidpryiemnytstvo $i$ torhivlya, vol. 21, pp. 119-128. (in Ukrainian)

10.Piatnytska, G., Hryhorenko, O., Dolzhenko, T. (2021). Dichotomy of enterprises' innovative transformations. Foreign trade: economics, finance, law, vol. 2, pp. 30-43. (in Ukrainian)

11. Piatnytska, G.T., Naidiuk, V.S. (2018). Multivariability of innovation development strategies. Foreign trade: economics, finance, law, vol. 1, pp. 22-36. (in Ukrainian)

12. Analytical Center «Restaurants of Ukraine» (2021). Rozvytok restorannoho hospodarstva Ukrainy za kilkistiu zakladiv [Development of the restaurant industry of Ukraine by the number of establishments]. URL: https://www.facebook.com/ 102348505275876/photos/a.114870357357024/114870250690368/?type=3 (accessed 28 May 2021). (in Ukrainian)

13. State Statistics Service of Ukraine (2014). Merezha rozdribnoi torhivli ta restorannoho hospodarstva pidpryyemstv na 1 sichnya 2014 roku [Network of retail trade and restaurant business enterprises on January 1, 2014]. Kyiv: SSSU. (in Ukrainian)

14. Poster (2020). Naskolko proseli po vyruchke zavedeniya v Ukraine v iyule 2020 hoda. [How much did the institution in Ukraine sag in terms of revenue in July 2020?]. URL: https://joinposter.com/post/prosadka-piviruchke-v-ukraine (accessed 28 May 2021). (in Russian) 
15. OpenTable (2021). The restaurant industry in recovery. URL: https://www.opentable.com/state-of-industry (accessed 30 May 2021).

16. Vinokurov, Ya. (2021). Year - plus, FOP - minus: how small business survived the first year of quarantine, Ekonomichna Pravda. URL: https://www.epravda.com.ua/publications/2021/03/24/672241/ (accessed 28 May 2021). (in Ukrainian)

17. Deloitte (2021). Spozhyvatski nastroi ukraintsiv u 2020 rotsi [Consumer sentiment of Ukrainians in 2020]. Deloitte \& Touche USC LLC. (in Ukrainian)

18. BizRating (2020). Kak rabotaietbiznes dostavky iedy [How the food delivery business works]. URL: https://bizrating.com.ua/6/articles/1395/index.html (accessed 28 May 2021). (in Russian)

19.Keefer, K. (2021). Restaurants are Investing and Innovating. URL: https://squareup.com/us/en/townsquare/futureof-restaurants (accessed 28 May 2021).

20.Petre, H. (2020). 28 mergers and acquisitions in the restaurant industry in 2020. Nation's Restaurant News. URL: https://www.nrn.com/mergers-acquisitions/28-mergers-and-acquisitions-restaurant-industry-2020 (accessed 28 May 2021).

21.Bovshovska, S. (2021). Why are social networks for business owners and CEOs a «must-have» in 2021? Business. URL: https://www.business.ua/uk/node/11462 (accessed 28 May 2021).

22. Otterburn, S. (2021). M\&A market overview - Restaurant and Bars 2021. BDO (UK). URL: https://www.bdo.co.uk/ en-gb/insights/industries/leisure-and-hospitality/restaurant-and-bars-2021-m-a-market-overview (accessed 28 May 2021).

23. Gonzalez, C. (2020). Restaurant Closings Top 110,000 With Industry in 'Free Fall'. Bloomberg. URL: https://www.bloomberg.com/news/articles/2020-12-07/over-110-000-restaurants-have-closed-with-sector-in-free-fall (accessed 28 May 2021).

24.Kinkartz, S. (2020). Coronavirus: Berlin's restaurants are dreading the Christmas season. $D W$. URL: https:/www.dw.com/en/coronavirus-berlins-restaurants-are-dreading-the-christmas-season/a-55618730 (accessed 28 May 2021).

25.Piatnytska, G., Fedulova, I. (2020). Financial safety of a country and an enterprise: definitions, interrelation and risks of providing, Efektyvna ekonomika, [Online], vol. 7. URL: http://www.economy.nayka.com.ua/?op=1\&z=8059 (accessed 28 May 2021). (in Ukrainian) 